\title{
Internações hospitalares e cirurgias precoces, linguagem e psiquismo: estudo de dois $\operatorname{casos}^{* * * *}$
}

\author{
Hospital internations and premature surgeries; language and \\ psychism: a two case study
}

\begin{abstract}
Malka Birkman* (malkabirk@yahoo.com.br)
\end{abstract}
Maria Claudia Cunha**

\begin{abstract}
* Fonoaudióloga. Mestre em Fonoaudiologia pela Pontifícia Universidade Católica de São Paulo. Endereço para correspondência: R. Venâncio Aires, 641 - Apto. 124 Torre 1 - São Paulo - SP CEP 05024-030

(malkabirk@yahoo.com.br).

**Fonoaudióloga. Professora Titular da Faculdade de Fonoaudiologia da Pontifícia Universidade Católica de São Paulo.

*** Trabalho Realizado na Pontifícia Universidade Católica de São Paulo.
\end{abstract}

Relato de Caso

Artigo Submetido a Avaliação por Pares

Conflito de Interesse: não

Recebido em 13.02.2005

Revisado em 12.05.2005; 25.10.2005; 06.12.2005; 7.03.2006

Aceito para Publicação em 7.03.2006.

\begin{abstract}
Background: mutual influences between body, psychism and language. Aim: the purpose of this work was to analyze the possible connections between hospital internations and surgeries, to which children were submitted at their earliest life years, as well as subsequent language and psychic adversities. Method: it is a qualitative/clinical research, of a descriptive/interpretative nature, carried out through the longitudinal analysis of two clinical case studies with small children of approximately three years of age, whose families had co-occurrent complaints: surgeries and premature hospital internations (as a consequence of organical diseases) and subsequent language disorders. Clinical material was analyzed under a theorical perspective, articulating psychoanalytical and speech therapy theories, based on clinical practice. Results: in both cases, speech therapy symptoms decreased progressively as the organic disorders gained space during therapeutic dialogues (between speech therapist and patient), as well as in home-circle narratives. This promoted modifications/surpasses of the language symptoms presented by the patients. Conclusion: the organic birth of the studied children was not concomitant to their symbolic birth, thus creating a gap between them. This gap is derived from the lack of compatibility between the development of corporal scheme and subjective processes. The symbolic effects suffered by parents due to the birth of children who are radically divergent from what was expected was devastating, making it impossible for parents to conceive their babies symbolically. After the violent impact of disappointment, these children remained being interpreted by their parents. This created a disturbance in the functioning of language and in the psychism of these children. Thus, unconsciously, parents were only able to represent their children based on the place that was originally given to them: the place of disease.
\end{abstract}

Key Words: Clinical Method; Language Disorders; Language; Psychism.

\section{Resumo}

Tema:influências recíprocas entre corpo, psiquismo e linguagem. Objetivo: este trabalho teve por objetivo estudar as possíveis relações entre internações hospitalares e cirurgias, sofridas por crianças nos seus primeiros anos de vida, e transtornos de linguagem e psíquico subseqüentes. Método: trata-se de uma pesquisa clínico-qualitativa, de natureza descritivo/interpretativa, realizada através da análise longitudinal de dois estudos de casos clínicos de crianças pequenas, com aproximadamente três anos de idade, cujo discurso familiar apontava para queixas co-ocorrentes: cirurgias e internações hospitalares precoces (em função de desordens orgânicas) e transtornos de linguagem subseqüentes. O material clínico foi analisado numa perspectiva teórica que articula teorias fonoaudiológica e psicanalítica, a partir da prática clínico-terapêutica fonoaudiológica. Resultados: em ambos os casos, os sintomas fonoaudiológicos reduziram-se progressivamente, na medida em que, os transtornos orgânicos ganharam circulação discursiva tanto no diálogo terapêutico (entre fonoaudióloga e paciente), quanto nas narrativas familiares, o que promoveu modificações/superações dos sintomas de linguagem manifestos pelos pacientes. Conclusão: o nascimento orgânico das crianças estudadas não foi concomitante ao nascimento simbólico formando-se, entre ambos, um hiato derivado da falta de compatibilidade entre o amadurecimento do esquema corporal e dos processos de subjetivação. Os efeitos simbólicos operados nos pais, em função do nascimento de um filho radicalmente diferente do desejado foi devastador, deixando-os impossibilitados de conceber os bebês simbolicamente. Passada a violência do impacto da desilusão dos pais, essas crianças permaneceram sendo lidas por eles desde a doença, o que criou transtornos em seus modos de funcionamento de linguagem e psíquico. Assim, inconscientemente, só poderiam representar os filhos desde o lugar que lhes foi originalmente destinado: o lugar da doença. Palavras-Chave: Método Clínico; Transtornos de Linguagem; Linguagem; Psiquismo. 


\section{Introduction}

In the history of speech-language patients the pain is present either in the silence or in the confusion of their speech, placing the listener in an awkward position when pointing the uneasiness of those who claim for attention beyond the body, once they are marked by radically human phenomena: the language and the psychism, that shape and transform the organism and are reciprocally affected and transformed by it (Eliacheff, 1995). In the perspective of bio-psychic receptiveness of the patients, it is observed that their bodies carry the marks of their histories.

The family reports emphasize the physical development of children even before birth, that is, the parents symbolically fantasize and expect that a son-subject may come from this body. Thus, the child becomes the parents' symbolic (besides genetic) inheritor (Abadil, 2004).

Admitting that the body humanizes from the attention provided since the intra-uterine life (Dolto, 1999), allows us to think that babies and small children reserve specificities regarding their fragility and the power of their bio-psychic functioning.

Therefore, when the expected baby does not correspond to what is presented to the parents, he becomes an impostor generating a gap derived from the incompatibility between fiction and reality, once the parents feel unable to recognize themselves in the child (Terzaghi \& Coriat, 2000).

The authors stress that the therapeutic work takes place exactly in this gap: where the parents and the children are expelled from their natural positions. In this direction, some typical contexts of speech-language science field may be cited: the cleft palate, the genetic syndromes and other congenital abnormalities, for example.

Under these circumstances, the parents are usually not provided with knowledge about the first aids for the baby in the hospital, once they are not "normal" children. The mothers can only operate under certain circumstances, when "affected by the situation of a newborn with life risk" (Jerusalinsky, 2000, p.55), they start to take different actions from the spontaneous ones.

In the prematurity context, it is frequent that they can not offer themselves to the babies as privileged carers, regarding the eye contact and the movements and sound production listening (so primitive in this initial moments of life). The baby is being organically saved in the intensive care unit (ICU), however "it is only from the parental speech that this life can actually have some symbolic meaning" (Jerusalinsky, 2000).

Dolto (1992), reports that the body is constituted by the body scheme (the reality itself, the body conscious structure) and the body's unconscious image (the internal image that the subject has of himself, unconscious and preconscious). However, the subject with some kind of deficit in his body scheme (for example, a congenital malformation) may have a healthy image of the body, fantasizing situations that he wouldn't be able to perform through the scheme (such as running, dancing). This may occur if the environment the subject is in, is not anguishing, specially regarding the parents; when his handicap and dreams can be transformed into words and be heard by someone who truly listens to him. The inverse is also true, according to the author. There are cases of subjects without lesions who, for example, can not perform some motor tasks, even without organic impediments, because they have built an unconscious ill image of their bodies.

Thus, the body is constituted beyond the soma, through the image the other has of it. Concerning the language development, the subject speaks since the moment when he is spoken of, trying to correspond to the image that is attributed to him. According to Souza (2000), the speech is more than just corresponding words to objects; it implies necessarily an addressing to the other and, consequently, a dialogue establishment.

Assuming the perspective of reciprocal influences between body, language and psychism, this study relates two case studies of small children who came to a speechlanguage clinic around three years old with a language disorder complaint (and psychic in one of the cases) and with a story of hospitalizations and early surgeries due to organic disorders (case 1: agenesia of cardiac ventricle, case 2.: ambiguous genitalia).

The early diagnosed disorders' history did not justify a direct causal etiological relation with language problems (neurological dysfunction, oral-motor or hearing disorders, genetic syndromes, etc.). On the contrary, the 
lesions of the organs did not impede or made the speech production difficult, in terms of anatomophysiology.

From this theoretical review and from the clinical experience, the purpose of this study was to analyze the possible relations between hospitalizations and surgical interventions suffered by the children in their first years of life, and the subsequent language and psychic disorders.

\section{Method}

This research was approved by the Ethics Committee of the Institution where it was developed (protocol 0116), and assured not to present risks or discomfort for both subjects who had their identities preserved.

It is a clinical-qualitative research of a descriptive type. Therefore, we don't propose statistical generalizations, but the establishment of analytical indicators.

The topic is analyzed in a perspective that articulates the speech-language therapy and the psychoanalytic theories from the speechlanguage clinical practice, evidencing the reciprocal influences between body, psychism and language.

The clinical material was composed by the case studies of two children attending a speechlanguage clinic, with language disorders complaints and who were hospitalized and suffered early surgical interventions.

The case reports do not intend the literality of facts, but rather to narrate the memories of the most important aspects of the experiences obtained during individual therapeutic meetings, registered after the sessions.

According to Nasio (2001), a clinical case is a fictitious reconstitution once it is a reinterpretation of facts throughout the experience filter of the therapist. As Cunha (2000) proposes, the registrations allow the speech pathologist to re-signify the clinical- therapeutic experiences. The recordings do not have to follow the facts chronology, but the memory atemporality, privileging the affection order.

\section{Subject 1}

Pedro (3,0 years old) presented phonemic disorders characterized by assystematic substitutions and distortions of the consonantal occlusive phonemes / $\mathrm{t} /$ and $/ \mathrm{d} /$. In addition to these problems (that many times limited the speech intelligibility), the patient received the diagnosis of a severe cardiac pathology soon after birth (ventricular agenesia). He underwent surgery on the third day of life and remained in the ICU during the first week of life (around nine days). The doctors informed the parents soon after the surgical procedure that Pedro would have 25 years of life prognosis and that he would be submitted to other palliative cardiac surgeries along the years.

\section{Subject 2}

Renato (3,6 years old) did not speak; he rarely murmured, was agitated and disperse. The mother complains of oral language and neuropsychomotor development delays. From the first moments of life, her relationship with her son was very disturbed due to the information received yet at the labor table: the baby' sex was undefined ("hermaphrodite"), thus she couldn't give him a name until the exams to which he was submitted were concluded. After a two months investigation, Renato underwent a genital corrective surgery (he was a boy). Concomitantly to the speech-language treatment, the patient was attending psychotherapy during the whole process. According to the psychotherapist, the patient presented a kind of very primitive functioning, characterized by psychotic traces.

In both cases, the speech language therapeutic sessions occurred weekly for a long period of time (approximately three and a half years), allowing a longitudinal study.

\section{Results}

Subject 1

Initial interview with the parents

The parents were requested to present the complaint. The father ironically said: "he is a very annoying boy". Both consensually said that their son is an insistent child for whatever he desires, "he wins because he tires people out".

Concerning the speech problems, they were very brief and reported he had a "tatibitati", and gave some examples: instead of "você" he says "votê" and instead of "bibi" he says "bumbum".

The examples given to illustrate the son's "tatibitati" did not totally correspond to the 
technical definition of the term. Therefore, they seemed to demonstrate a lack of authorship in the production of this term, possibly reproducing some professional's speech. This discourse, among others that followed, masked the impossibility of creating their own speech about their son, perhaps to protect themselves against suffering.

Then, they started a long report about Pedro's cardiac problems, from which we point out the essential elements: three days after birth the child underwent the first repairing cardiac surgery and was released on the 12 th day with a medical prognosis of a "25 years of life". One year later, he underwent another cardiac surgery remaining in the hospital for 12 days.

The parents accompanied him during all hospitalizations, however when he was at the ICU, the visits were limited to certain times, determined by the hospital. While in the hospital bedroom, the touches and managements were limited due to the sutures and to infection risks.

After the second surgery, the doctor told them that Pedro could have some kind of motor and/or speech delay due to the trauma caused by the isolation suffered during the post-surgical period (five days).

Pedro did not crawl and by the time of the second surgery he was a very agitated child. The mother said: "apart from the cardiac problem, he is a normal child" and complemented "I'll be honest with you, I understand almost everything he says. We are seeking for help because of him (referring to the husband), everything is fine by me". The father justified: "if we did not look for help, certainly Pedro would have problems in the future".

The therapeutic process of Pedro

It was observed in the patient's speech, backing of phonemes /t/ and /d/ (substituted either by /k/, or by /g/). For example:"quéo bincá díco"/quero brincar disto, "de méc côcal" /de Mac Donald's, "maca" and "maga"/mata". Such persisting alterations, although assystematic, were always associated to a vocal hyper-nasality.

Despite the intelligibility flaws in his speech caused by such problems, Pedro was understood due to four reasons: 1) the prosody, that gave supra-segmental support to the produced segment; 2) the utterances with authorship, not restrict to specular conducts regarding the therapist's ones; 3 ) the skill to assume the interlocutor's role in the dialogue context; 4) the therapist reliance on his utterances, searching to interpret them and give them meaning to beyond the patient's limitations concerning the linguistic code mastery in its formal dimension.

Summarizing, the language acquisition process seemed to be adequately processed, considering his age.

In the first sessions, Pedro did not want to enter alone, asking the mother to follow him. She remained in the room for some while, leaving afterwards. However, when she was mentioned in the play she had to be empirically brought to the session, and not just imaginarily.

When the speech pathologist didn't understand what Pedro had said, he ignored her sometimes or repeated what he had said exactly the same way.

Once, Pedro asked the therapist to remove the "capacecri" (capacete/ helmet) of a doll. When asked about what he had said, he did not respond and kept playing.

In another moment, in a similar context, he asked the pathologist to put the "capacecri" on the doll. When asked, Pedro answered emphatically: " capa - ce - cri!".

Some months after, he was singing: "acrirei o pau no ga co cô, mais o ga co cô..." (atirei o pau no gato-to, mas o gato-to...). The therapist asked if the cat had pooped (cocô) and Pedro laughing, denied.

This was a pioneer moment, when the patient was able to hear himself and mainly, he could realize the semantic alteration due to phonemic alterations. Such tool, of dialogic nature, became efficient regarding the reduction of the articulation symptom.

Still, due to the phonemic disorders characteristics, the velopharyngeal dysfunction was investigated. The phonoarticulatory clinical exam showed the integrity of its anatomofunctionality. Furthermore, the non-systematicity of the phonemic productions contributed for the minimization of the hypothesis.

However, the articulation problem remained. Once, Pedro asked to play with some miniature animals, among them a turtle. The "cacaruga-mãe" (tartaruga-mãe/ mother-turtle) was responsible for taking care of the "cacaruga" (tartaruga/ turtle), giving it food, bath and affection. 
The therapist asked him if the turtles were dirty, "with caca", and therefore they were "cacarugas". And, if so they should take a bath. They bathed the "cacarugas" and when they were clean, he started to call them "tartarugas" (turtles). The tongue (anatomo-physiological structure) suffered the symbolic effects of language.

After one year of therapy, significant changes occurred in Pedro's speech. The phonemic backing accompanied by hyper-nasality was gradually disappearing.

Nevertheless they persisted, although less frequently. On one occasion, they were doing animal mimics and the therapist imitated an alligator. Pedro shouted: "racaré!" (jacaré/ alligator). "Racaré?", asked the therapist and he corrected: "não, zacaré!". He did not pretend not to listen anymore, nor repeated the previous production the same way. He seemed to start to listen to himself and search for a new phonological pattern, even if inadequate.

Another example: Pedro noticed that the rug was interfering with his movements. The therapist asked: "do you want me to remove it?". "Yes, the ta-pe-te" (rug) he said, producing the word syllabically.

Back to his story: when Pedro was born, his family was informed he could be a normal child if he did not have his congenital cardiac problem. "Only this was missing" for him to be perfect. The same way, in his language "only that was missing" (to produce /t/ and /d/ adequately).

This position defined an existing condition for him: that always something is missing, failing. A residual mark meaning that "everything would never be all right" pointing to a morbid story suffered by the body, and that did not mark only the "body structure" (Dolto,1992); but also the symbolic body structure of the subject. Therefore, deep marks were created in the "unconscious image of the body" (Dolto, 1992).

In the following year, next to his birthday date, he wanted to blow a balloon. As he was having difficulties to do so, he asked the therapist for help.

The first attempts failed and he cried wanting to give up Convinced by the speech therapist, he tried again. She held the balloon and he blew it. When he finally could do it, he was amazed with the balloon growing with the air coming from him. He drew a face on each balloon he blew. Then, he suggested the whole body should be built, "a robot".

Pedro drew the face and tied the balloons together and noticed that one of the legs was badly positioned. When he tried to solve the problem, the balloons blew up and he got desolated.

The therapist and him blew other balloons and the "robot" got new body parts. On its abdomen, Pedro made a drawing and said: "it's a female robot pregnant of a boy". He decided then he would give it as a present to his mother.

Pedro had incorporated the body notion as an unit, reconstituting it without flaws, with creativity; maybe symbolically generating a new possibility of life, a new existing condition. Would "another boy" be breeding?

On the third year of therapy, he would complete six years old. After his birthday he came to the session with a miniature car, announcing he had won it from his "cria" (tia/ aunt). There it was, the persistent symptom.

Certain day he tells: "you know, the other day I watched a TV show where Chiquinha from Chaves had a heart attack". The therapist asked him what was a heart attack, and he answered: "it's when you feel a strong pain in the heart [pressing his hand against his chest]. Then you have to go to the doctor and do a lot of exams". It is worth it to stress that he never before mentioned his cardiac problem. It seemed, though, the issue was not "a secret" anymore and got a meaningful discursive circulation.

When he referred to the pain, exams and doctors he seemed to be talking about himself, about something he had experienced "on his own body". As reports Eliacheff (1995), it is through words that corporal disturbances are transformed into psychic experiences. And this was a marker for subsequent changes in his language.

The next session, Pedro proposed: "let's play with Lego? Let's build a building?". While playing he commented: "you know, my mother told me that soon I won't need to come here anymore, because I'm already speaking all right". And he really was.

At the end of the subsequent session, the mother told that since the past session Pedro was showing the parents he knew how to produce /t/ and /d/ ("tia and prédio"), proud of himself.

\section{Subject 2}

\section{Interview with the mother}

Since the beginning of the interview, Renato's mother talked uncontrollably presenting a speech followed by crying and pain expressions. She connected several stories, making difficult the comprehension of her report. 
It was possible, though to get the essential content: Renato was born at term by cesarean section and presented fetal suffering. (because of unknown causes). During the pregnancy she underwent pre-natal exams accompanied by a doctor and everything indicated she would have a "normal child".

Immediately after the child's birth, she was informed by one of the nurses that his son was born with a "penis atrophy". The child actually was born with ambiguous genitalia and, in order to define the sex it was necessary to do a genetic exam (karyotype).

Three days after the birth, mother and son were discharged from the hospital. The birth party became mourning, since according to Terzaghi and Coriat (2000) an "impostor" was born.

The investment on the expected child was misplaced as a child without a sex that could be defined by a simple observation of the body scheme, was born.

Thus Renato couldn't get a name until approximately two months of life, when the results of the karyotype were obtained. In this time interval, he was called baby, angel (the one without a sex?) by the relatives.

According to the mother, during the period the sex was unknown, the doctor advised her to answer that he was a very sick baby, when she was asked about the baby's sex.

When he was four months old, he underwent a surgery (perineal hypospadia degree III), aiming at the reconstitution of the urethra in the interior of the penis.

The mother was dismissed by the medical team to give her son the natural care, which was centered in the organism and aimed at investigating and treating him.

Since birth, the child was separated from the parents many times, either physically (because of the several clinical exams and the corrective surgery), or symbolically (who is this son?). Thus, he couldn't find at this moment of despair, a welcoming environment that could give him the effective symbolic existence.

The mother was informed that Renato wouldn't suffer any subsequent developmental damage. Nevertheless, she noticed an early neuropsychomotor development delay: "the motor development was a bit slow, he wasn't sitting" (he was able to sit with support when he was nine months old).

She said the boy wasn't interested by anything: "if you hide something he was playing with, he looses interest almost immediately. He didn't have eye contact, he seemed to look through me as if there was no one in front of him".

The mother's speech, many times, was similar to a medical speech; it was at the same time informative (from the organic aspects point of view) and empty of subjectivity. Sometimes she spoke as a doctor, and sometimes as an educator, but rarely "as a mother".

Renato wasn't breastfed because he couldn't suck. He was fed by a syringe or by a bottle with a small beak. She reported that that was a very frustrating period for both (herself and Renato): "there was a lack of intimate contact between mother and child and I think he felt it. Maybe this is why he is so distant until today".

With a few months of life, Renato suffered an accident: while the mother was preparing his food, he fell down the feeding chair and didn't cry. Worried, the mother searched for neurological exams.

The Computerized Tomography indicated "signs of diffuse encephalic volumetric reduction", a finding that didn't correspond to the consequences of the fall, according to the neurologist, who added that Renato presented a psychotic behavior typical from "Developmental Pervasive Syndrome with a high functioning autistic-like behavior".

He was then submitted to an audiological assessment once there was a suspicion of hearing loss as "when he was concentrated doing something, he wasn't affected even by a loud noise. He didn't jump or realize what had happened". Conversely, there was a paradox in other situations: "a pheasant could fall and he would look at it".

He underwent a brainstem audiometry (BERA) and the results showed a slight thresholds lowering for the stimulus used, not excluding a conductive component. Prolonged waves III and V, more evidently on the right, suggesting a possible myelinization disorder of the brainstem auditory pathway.

With that amount of clinical information, the mother decided to enroll herself in health courses given by health professionals in order to learn how to deal with her son. The gap between them was even bigger, once she tried to understand her son professionally. It was possible to observe that the professional speech substituted the maternal one. 
As Renato's body developed, the exams were repeated and the recent results denied the previous ones. For example, the central deafness hypothesis was eliminated. The mother was feeling guilty for the autistic behavior of the son, which according to her, would have as a cause the trauma after birth: "trying to help, I ended up harming him. I took him to suffer (referring to the exams he underwent)... it's a trauma being held so many times".

Then, she reported that the husband didn't agree the son needed so many treatments, refusing to see the professionals involved.

The issues regarding the sexuality were always the most touching ones.

It is known that all babies are born with a sex (with some genital organ), however without a definite sexuality; therefore, "hermaphrodite" considering the subjective constitution (body image). From this possibility, derives the expectations of the other on the baby's body, the attention given to him: the touch, the feeding, the voice carrying a message for him. The other's desire prints marks that outline, attribute limits, sculpt the baby's body, establishing the I/ other relations.

It is the other offering himself as a mirror, as a place where the child's sound productions may resound, attributing possible meanings to the child's vocalizations (in the specular processes).

The therapeutic process of Renato

When he was three years and a half, Renato came to the speech-language clinic walking with enlarged base and asymmetric and unbalanced steps. He seemed to look through the therapist who was holding his hand, and did not realize that his escort was not the mother anymore. He didn't speak, didn't look at people nor at the objects, tripped and touched everything around him(people and/ or objects).

He randomly produced some vocal sounds as mere motor discharge, without any intentionality. His sound productions were not directed to the therapist, they pointed to a very primitive type of human functioning.

His look was disperse, captivated by the lights and colors of the objects and there was an evident refusal to any interpersonal contact. He sweated a lot, lied down on the floor, stood up, ran, sat, stood up, fell, tripped, as he were discharging those visual stimulus he had captured with motor activities.
He moved quickly and with autonomy, however his body seemed not to have contours. He predominantly sat in a "w" position, his articulations seemed not to have restrictions. When he fell, he didn't seem to feel pain or to cry. He manipulated the objects, touched them one by one and them got rid of them. If he was touching an object and the speech pathologist removed it from his hands, he didn't look for it, nor resisted to the removal. Furthermore, the physical approximation of the therapist made him go to the opposite direction from her.

There was only one moment when he touched the therapist: when he needed to get something he couldn't reach, using her body as an extension of his own.

In the first sessions, the therapist called him by his name, sang some songs that maybe were familiar to him trying to establish contact with him, but nothing happened. Conversely, if she turned the fire truck on (with lights and noises) or shook some sound object, he would almost immediately turn his attention to those objects.

The signs moved wildly in the metaphoric and metonymic axis. This signs dispersion was characterized by the lack of contention in the symbolic functioning. Any sign could be substituted by any other, at any position of the chain.

Talking to the psychotherapist who assisted him (for a year), she reported that Renato behaved the same way with her as he did with the speech pathologist in the first sessions. She pointed the precarious psychism of the patient, characterized by evanescence. It is worth it to stress that both treatments (speech-language and psychoanalytic) started to occur simultaneously.

The psychotherapist reported that Renato improved since the beginning of the treatment, he was less dispersive, started to have eye contact, although she pointed that the speech events were very rare. According to her, the patient presented a very primitive type of functioning, characterized by psychotic traces.

Renato was fascinated by books, looked through them, pointed with his indicator finger letters and numbers, without focusing the drawings. After one years and six months therapy, in a certain session the therapist collected the book from his hands, placing it in a high place he couldn't reach, and offered him a toy, after all he still "ignored" her.

Surprisingly, he kept on pulling the therapist pointing to the place she had put the book. When she denied getting it, he started to cry and said: 
"mã-mã...". This was the first time he said something that could be understood.

During the whole process, the discursive fragments produced by Renato, understandable or not (from the linguistic code point of view); as well as his body gestures were interpreted by the speech-language therapist who searched to give them meaning, assuring his position of interlocutor.

When he said "mã-mã..." the speech pathologist answered: "you want the book and as I didn't give it to you, you call your mother to help you, don't you?". As she spoke, Renato clamed down, and waited for the delivery of the wanted object.

The speech-language technique comprised capturing the patient's disperse verbal and nonverbal productions and insert them in the syntax. That is, attributing the value of a symbolic activity on those primitive gestures.

When the mother was present in the sessions, she named each object that Renato touched. She spoke to her son but addressed the speech to the therapist. "Did you tell her that you got a new sheet?". Renato murmured a lot, producing vocalizations, but they were not considered as language by the mother.

Therefore, the therapist started to point out: "did you realize he spoke something?". And she answered: "yes, he did but I don't understand".

On one occasion, Renato was running across the room with a car in his hand and the therapist asked: "you want to play with the car, don't you?". After a while he answered: "é" (yes). The mother was indifferent to her son's speech and the therapist asked her: "did you hear what he said?", and she said: "I heard, but he was looking to the other side, he didn't seem to be speaking".

During the sessions she was present, Renato sometimes murmured and sometimes he kept a distance touching something alone; in another moment he got closer with some toy in his hands. While this was happening between the three, the speech therapist searched to interpret his gestures and vocalizations.

Some time later (approximately two and a half years), the mother started to be captured by the sound fragments of the son and anticipated a speech gesture value on them. As she intensified her listening to him, Renato presented transformations: he was less disperse, he could symbolically play, although sometimes the vocalizations were scarce.

The fusional tendency of the mother - son relationship remained. Renato would get over the mother's back, pull her down to the floor and both of them would lie down on the floor, with their bodies together, excluding the therapist from that game.

These situations reserved only two positions (while there were supposed three): the speech pathologist one and the mother+son. They were fused in only one body and between them nothing needed to be said. Thus, the speaker position was reserved to the mother, who spoke for both of them.

The time was passing by, and although it was possible to observe significant changes in Renato's behavior and language, they were still delayed considering the natural parameters of development for his age.

Within the symptoms, when he was six years old Renato still wore a dipper for his physiological needs. In these moments, the mother entered the room to clean him up.

He had a body scheme of a six year old child and a body image of a baby. He had several motor skills compatible with his age; however concerning the psychic and language acquisitions, he was delayed. Sometimes he seemed to understand what was said and sometimes he seemed not to listen.

However, the lack of sphincter control was a constituted symptom, regardless the speech pathologist's interventions aiming at the dipper removal. Certain time, bothered with the situation, the therapist told him emphatically: "you are a big boy already and your excrement smell badly, like a grown up's one. Feel the strong smell! Enough" You are almost seven and from now on when you want to go to defecate, you will use the toilette, as everyone else!".

This time something different happened. The mother watched the whole scene and told him: "did you hear what she said? You'll have to ask when you need to go to the toilette and will stay without dippers".

In the following session, Renato did not wear a dipper. According to the mother, he had passed to that phase "asking to go to the toilette". She said: "he spoke ah, ah, and I attended him". That is, she interpreted/ listened to him.

Subsequently, Renato intensified his vocalizations (we are on the third year of therapy!). On certain occasion, he pulled a box full of miniature cars, placing them around the floor. The therapist proposed they made a car shop: "so, you are the shop owner? I want to buy a car. He got one of them and she asked "how much does it cost?.

He looked straight at her, as he never did before, and said "têis" (três/ three), and still looking at her, continued: "reais". 
In another session, his mother and he were embraced, playing when the therapist suggested that all the three of them played. Sitting on his mother's lap he said "dois" (two). The mother smiled, saying she loved him very much, but that they would play with the therapist as well.

The mother's investment in the dialogue with the son was greater: "tell the therapist what you ate yesterday? Mashed... (waiting for the son to complement), and he said: "potato". And the therapist built a text for that speech "humm, delicious mashed potatoes".

Six months later, during a session, Renato did something that unpleased the mother and she firmly reprehended him, with authority: finally, she was speaking to him. Renato sat and cried, looking at her with a sad face expression.

The message addressed to him through language was effectively reaching him, causing effects. While crying, he said "mã, mã", looking at her. And she responded: "there is no use to call me now because I'm very upset with you". At last his enunciates were captured and inserted in a meaningful net that, dialogically, returned to him.

Renato started the speech-language treatment with an oral language acquisition delay, characterized by the absence of orality and rare murmurs.

With the speech-language therapy, he started to speak, even if partially in formal linguistic terms. Simultaneously, his look began to oscillate between the dispersion and the intentionality. His body acquired limits: he started to walk and sit properly, the unrestricted articulations gave place to contention. The manipulation of objects gave place to playing (the games began; many times with turntaking between the therapist and him). He acquired sphincter control starting to ask to go to the toilette through a speech accompanied by gestures, although he refused to hold his own penis to urinate. Language and body changes occurred simultaneously. A subject-boy was being born, even if late.

\section{Discussion}

Renato and Pedro: children with language problems complaints, both of approximately the same age and with peculiar stories.

During the first interviews the parents of both children reported in details the organic issues of the children. They even used technical terms to describe them with a better precision, but said very little about the language issues.
It was interpreted that the parental demand for the speech-language treatment referred to the organic disorders suffered by the children, as well as to the language matters. The therapeutic meetings were marked by the manifestation of suffering (Palladino,2000).

But why such demands, concerning cardiac and genital matters respectively, were being addressed to a speech-language pathologist?

Analyzing the cases, it was understood that these children's life stories were linked to a pathological condition of existence, since always. Their bodies were being constituted, welcoming and interpreted from their morbid stories.

The heart and the genitals are organs that do not have a direct relation, anatomically and functionally, with the speech. Thus, in a direct causality relation these stories do not relate to the language matters. Therefore, in an approach centered in the organic functioning this information could possibly be "archived", once they have a secondary importance.

In this perspective, if the congenital lesion was placed in the oral region (for example, a cleft palate), Pedro's speech alterations would probably be associated to this lesion. If Renato were born with a profound hearing loss, for example, equally this organic data would gain importance in the speechlanguage discourse regarding the language problem.

Souffont (2004) reports the therapy of a two years old child with feeding disorder; after an investigation, it was verified that there was no organic problem. In the speech-language field, Palladino, et al.,(2004) also discuss this theme.

Such proposals indicate that the body matters should be analyzed beyond the organic functioning. For example, the profound deafness in children with severe psychic and language disorders don't justify, alone, such symptomatic manifestations.

It can be stressed that any body story deserves a privileged attention by the speech-language pathologist. Because the organic illness should not be understood as something "foreign" to the subjectivity, but as something "produced" by the subject, as a solution found to solve a deep and consciously inaccessible conflict.

Thus, the children's language disorders in both cases seemed to be the most powerful solution 
found to call the other (mainly their parents), asking for help.

The subjectivity processes involve necessarily the quality of the interpersonal relationships, the expectations (specially the mother's) about such a delicate and dependent baby's body, searching for a possible identification.

In these cases (Pedro and Renato), the symbolic effects originated from the birth of radically different children than the expected ones were devastated for the parents, not allowing them to symbolic welcome their babies.

\section{Conclusion}

1. In both studied cases, it could be suggested the existence of relations between the surgical interventions and/or hospitalizations suffered by children in the first years of life and subsequent language and psychic disorders.

2. In the speech-language practice, the clinician should consider all data related to the organic history of the patient, not only those concerning the nervous, oral-motor and/or auditory systems. 3. The language pathologies of the studied patients had a strict relation with the physical and affection privation situation to which they were submitted regarding their parents. Therefore, it can also be stressed that the family counseling practice (that is, "teaching" strategies to deal with the manifested symptoms) does not guarantee that the family can symbolically deal with the child.

4. The organic birth of these children was not concomitant to the symbolic birth, forming a gap between them, a compatibility failure between the body scheme and the subjectivity processes maturations. These children were always interpreted by their parents from the disease, from the impossibility of performing something, causing disturbances in their functioning mode. Thus, it was like they unconsciousness knew that something had to malfunction. They could only speak from the place they were put, that is, from the disease place.

\section{References}

ABADIL, V. Troubles de l'oralité du jeune enfant. Reeduc. Orthoph., Paris, v. 42, n. 220, p. 55-68, 2004.

CUNHA, M. C. Desesquecimento: sobre a escolha do material clínico na pesquisa fonoaudiológica.Dist. Comun., São Paulo, v. 12, n. 1, p. 91-99, 2000.

DOLTO, F. Tudo é linguagem. São Paulo: Martins Fontes, 1999. $162 \mathrm{p}$.

DOLTO, F. Imagem inconsciente do corpo. São Paulo: Perspectiva, 1992. 313 p.

ELIACHEFF, C. Corpos que gritam: a psicanálise com bebês. São Paulo: Ática, 1995. 149 p.

JERUSALINSKY, J. Do neonato ao bebê: estimulação precoce vai à UTI neonatal. Estilos Clín., São Paulo, v. 5, n. 8, p. 49-63, 2000.
NASIO, J. D. As três funções de um caso: didática, metafórica e heurística. In: NASIO, J. D. Os grandes casos de psicose. Rio de Janeiro: Zorge Zahar, 2001. p. 11-22.

PALLADINO, R. R. R. A objetividade e a subjetividade na fonoaudiologia. Dist. Comun., São Paulo, v. 12, n. 1, p. $61-74,2000$.

PALlADINO, R. R. R.; SOUZA, L. A.; CUNHA, M. C. Transtornos de linguagem e transtornos alimentares em crianças. Psican. Univ., São Paulo, n. 21, p. 95-108, 2004.

SOUFFONT, V. Dysoralité: prise en charge orthophonique de Victor, deux ans, nourri par nutrition entérale à debit continu (NEDC). Reeduc. Orthoph., Paris, v. 42, n. 220, p. 169-177, 2004.

SOUZA, S. P. Um lugar para falar... Estilos Clín., São Paulo, v. 5, n. 8, p. 156-169, 2000.

TERZAGHI, M. A.; CORIAT, H. L. Fundamentos e limites da estimulação precoce: algumas reflexões. Estilos Clín., São Paulo, v. 5, n. 8, p. 18-23, 2000. 